\title{
Pengaruh Edukasi Perubahan Gaya Hidup Sehat terhadap Clinical Outcome pada Pasien di Rumah Diabetes Universitas Surabaya
}

\author{
Retna Eka Dewi', Sulistyo Emantoko Dwi Putra², Lisa Aditama', Heru Wijono³ \\ ${ }^{1}$ Program Studi Magister Ilmu Farmasi, Fakultas Farmasi, Universitas Surabaya, Surabaya, Indonesia \\ ${ }^{2}$ Fakultas Teknobiologi, Universitas Surabaya, Surabaya, Indonesia \\ ${ }^{3}$ Rumah Sakit Husada Utama, Surabaya, Indonesia \\ Korespondensi: Retna Eka Dewi \\ Email: retnaekadewi14@gmail.com
}

Submitted : 01-09-2020, Revised : 02-09-2020, Accepted : 07-12-2020

\begin{abstract}
ABSTRAK: Prevalensi diabetes melitus yang semakin meningkat setiap tahunnya cenderung meningkatkan risiko komplikasi dan kematian akibat diabetes melitus itu sendiri. Tujuan penelitian ini adalah untuk mengetahui pengaruh edukasi perubahan gaya hidup sehat terhadap clinical outcome (parameter klinis) pada pasien di Rumah Diabetes Universitas Surabaya. Rancangan penelitian menggunakan one group pretest-posttest yang diikuti oleh 27 subjek diabetes melitus di Rumah Diabetes Universitas Surabaya. Seluruh subjek diberikan edukasi (intervensi) dengan perangkat piring sehat dengan durasi 4 minggu. Pengukuran clinical outcome dilakukan terhadap gula darah puasa, indeks massa tubuh (IMT), lingkar perut, dan tekanan darah. Uji statistika yang digunakan adalah Wilcoxon signed rank test dan paired t-test. Hasil penelitian menunjukkan bahwa edukasi perubahan gaya hidup sehat berpengaruh signifikan terhadap penurunan gula darah puasa $(\mathrm{p}<0,001)$, indeks massa tubuh $(\mathrm{p}=0,005)$, lingkar perut $(\mathrm{p}=0,005)$, tekanan darah sistolik $(\mathrm{p}=0,013)$, namun tidak signifikan terhadap tekanan darah diastolik $(\mathrm{p}=0,247)$. Dapat disimpulkan bahwa edukasi perubahan gaya hidup sehat berpengaruh terhadap gula darah puasa, indeks massa tubuh, lingkar perut, dan tekanan darah sistolik. Keterbatasan dalam penelitian ini adalah keikutsertaan penderita diabetes melitus yang sedikit serta tidak adanya kelompok kontrol sebagai pembanding.
\end{abstract}

Kata kunci: edukasi perubahan gaya hidup; diabetes melitus; parameter klinis

\begin{abstract}
Increased prevalence of diabetes mellitus every year tend to increase the risk of complications and death due to diabetes itself. Aim of this study was to determine the effect of modification healthy lifestyle education on clinical outcomes in patients at diabetes home of University of Surabaya. The one group pretestposttest design was followed by 27 subjects with diabetes mellitus at diabetes home of University of Surabaya. All subjects were educated with healthy eating modification lifestyle (intervention) using healthy plate for 4 weeks. Clinical outcome of fasting blood glucose, body mass index (BMI), waist circumference, and blood pressure were measured before and after received intervention.The statistical test used was Wilcoxon signed rank test and paired t-test. Modification of healthy lifestyle education significantly reduced fasting blood glucose $(p<0.001)$, body mass index ( $p=0.005)$, waist circumference $(p=0.005)$, systolic blood pressure $(p=0.013)$ but not significantly to diastolic blood pressure ( $p=0.247)$. Modification of healthy lifestyle education has effect on fasting blood glucose, body mass index, waist circumference, and systolic blood pressure. Limitations in this study are the low participation of people with diabetes mellitus and the absence of a control group as a comparison.
\end{abstract}

Keywords: modification of healthy lifestyle education; diabetes mellitus; clinical outcome 


\section{Pendahuluan}

Diabetes melitus merupakan kondisi kedaruratan global terbesar di abad 21. Sampai saat ini masih banyak negara yang belum waspada terhadap dampak yang dapat ditimbulkan oleh diabetes melitus. Diabetes melitus jika tidak terkontrol dengan baik, dapat menyebabkan berbagai macam komplikasi penyakit, diantaranya serangan jantung, stroke, gagal ginjal, impotensi, amputasi bagian tubuh dan kebutaan. Risiko kematian penderita diabetes secara umum dua kali lipat jika dibandingkan dengan seseorang yang bukan penderita diabetes. Sekarang ini prevalensi penyakit diabetes melitus tipe dua semakin hari semakin meningkat [1,2]. Peningkatan pola kematian yang diakibatkan oleh Penyakit Tidak Menular (PTM) terjadi pada tahun 2016 dari yang awalnya 57\% menjadi $71 \%$ [3]. Kematian yang diakibakan oleh diabetes melitus sebanyak 4,2 juta jiwa (setara dengan satu kematian setiap delapan detik), dimana 1,3 juta jiwa kematian berasal dari wilayah Western Pasific (dimana Indonesia berada di wilayah ini) [1].

International Diabetes Federation (IDF) memprediksikan prevalensi diabetes di dunia pada tahun 2019 adalah 9,3\% dan akan meningkat pada tahun 2030 menjadi 10,2\%. Jika ditotal jumlah penderita diabetes di dunia meningkat dari 463,0 juta jiwa pada tahun 2019 menjadi 578,4 juta jiwa di tahun 2030 [1]. IDF menyatakan bahwa Indonesia masuk dalam 10 besar negara dengan jumlah penderita terbanyak di seluruh dunia pada tahun 2019, yaitu berada pada urutan ketujuh dengan jumlah penderita diabetes melitus sebanyak 10,7 juta jiwa[1].

Peningkatan prevalensi diabetes melitus terjadi karena semakin hari pola hidup masyarakat semakin tidak sehat, terutama dalam hal asupan makanan, salah satunya adalah makanan cepat saji. Makanan cepat saji, selain cepat juga dianggap praktis, namun dibalik itu kalori makanan yang ditawarkan oleh restoran cepat saji juga tinggi. Berdasarkan data penelitian di Inggris, dari 27 restoran cepat saji, rata-rata total kan- dungan kalori adalah $977 \mathrm{kcal}$ (CI 95\% 973983)[4]. Hasil survei yang dilakukan pada tahun 2008 terkait konsumsi makanan cepat saji pada masyarakat Indonesia sebanyak 69\%, dimana makanan tersebut paling sering dikonsumsi pada siang hari, yaitu sebanyak 33\%, makan malam sebanyak 25\%, sebagai selingan sebanyak $9 \%$ dan sebanyak 2\% untuk makan pagi [5]. Kebiasaan masyarakat yang sering mengkonsumsi makanan cepat saji sangat berdampak secara signifikan terhadap kenaikan Indeks Massa Tubuh (IMT)[6].

Kebiasaan buruk lainnya adalah konsumsi minuman manis yang berlebihan. Sugar-sweetened beverage (minuman manis) mengandung gula seperti sukrosa dan fruktosa dalam jumlah tinggi, selain itu memiliki kalori yang tinggi dan memiliki nilai gizi yang sangat sedikit serta tidak dapat memberikan rasa kenyang seperti yang dapat diberikan makanan padat, sehingga asupan energi total dapat meningkat dan akhirnya mengakibatkan terjadinya kenaikan berat badan yang tidak sehat $[7,8]$.

Studi Diet Total (SDT) oleh Kementrian Kesehatan tahun 2014 yang dilakukan untuk melihat kecukupan gizi dari masyarakat Indonesia, terkait konsumsi gula, garam (natrium) dan lemak (GGL), menunjukkan bahwa masyarakat Indonesia mengkonsumsi gula lebih dari $50 \mathrm{~g}$ perhari (4,8\%), garam (natrium) lebih dari 2000 mg perhari dan lebih dari $67 \mathrm{~g}$ lemak perhari (26,5\%). Pola komsumsi makanan berlemak, kolesterol, dan gorengan $\geq 1$ kali dalam sehari pada masyarakat Jawa Timur sendiri adalah sebanyak 49,5\%. Asupan kalori dan protein pada masyarakat Indonesia masih belum merata, proporsi penduduk Indonesia dengan asupan kalori dan protein melebihi $100 \%$ sebanyak 18,3\%, dan tiga provinsi teratas yang penduduknya kelebihan asupan kalori dan protein adalah DKI Jakarta, Kep. Riau, dan Bangka Belitung $[9,10]$.

Penatalaksanaan diabetes melitus berdasarkan PERKENI diawali dengan menerapkan pola hidup sehat (pola makan dan akifitas fisik) bersamaan dengan pengobatan farmakologis, serta pasien harus diberikan edukasi agar bisa me- 
ngelola penyakit diabetes melitusnya secara mandiri. Salah satu edukasi yang diberikan adalah dengan edukasi tentang mengatur pola makan agar seimbang untuk bisa menjaga kadar gula darah menjadi terkontrol, selain itu juga diiringi dengan melakukan aktivitas fisik. Prinsip pengaturan makan pada pasien diabetes melitus hampir sama dengan anjuran makan masyarakat umum, yaitu makanan seimbang dan sesuai dengan kebutuhan kalori dan zat gizi masing-masing individu. Yang perlu ditekankan dari pengaturan makanan pasien diabetes adalah 3J, yaitu Jadwal, Jumlah, dan Jenis [11]. Di Indonesia sendiri juga memiliki program yang hampir mirip, yaitu 'ISI PIRINGKU' dimana program ini digunakan untuk menggantikan program 4 sehat 5 sempurna yang dahulu pernah ada.Tujuan program ini juga sama yaitu agar masyarakat bisa mengatur pola makan disesuaikan dengan kebutuhan tubuh mereka agar seimbang dan cukup gizi [12].

Edukasi gaya hidup sangat diperlukan untuk merubah suatu perilaku. Menurut American Diabetes Association perubahan suatu perilaku sangat diperlukan untuk memastikan kontrol gula darah yang baik melalui kepatuhan terhadap pengobatan dan diet, pemantauan mandiri gula darah, merancang pola makan sehat, melakukan latihan fisik 50 menit setiap minggu, dan tindak lanjut untuk kontrol ke dokter [13]. Hasil suatu studi meta-analysis pada tahun 2003 menyatakan bahwa pemberian edukasi dan intervensi tentang kebiasaan hidup sehat berdampak positif pada kadar gula darah puasa [8].

Penelitian ini bertujuan untuk menganalisis pengaruh edukasi perubahan gaya hidup terhadap perbaikan clinical outcome (indeks massa tubuh, lingkar pinggang, tekanan darah, dan gula darah puasa) pada penderita diabetes melitus tipe 2 pada pasien di Rumah Diabetes Universitas Surabaya.

\section{Bahan dan metode}

Penelitian ini menggunakan rancangan one group pretest-posttest study design dengan vari- abel bebas edukasi perubahan gaya hidup dan variabel tergantung adalah clinical outcome (parameter klinis) yaitu indeks massa tubuh, lingkar pinggang, tekanan darah sistolik, tekanan darah diastolik dan gula darah puasa.

\subsection{Subjek penelitian}

Penelitian dilakukan pada pasien di Rumah Diabetes Universitas Surabaya dengan kriteria inklusi merupakan pasien diabetes tipe 2 dengan lama menderita diabetes $\geq 10$ tahun yang memiliki permasalahan dalam pengaturan pola makannya serta bersedia mengikuti penelitian sampai akhir dengan mengisi inform consent. Kriteria eksklusi penelitian ini yaitu peserta yang memiliki asupan berbeda dari orang normal seperti, sedang hamil dan menyusui, sedang dalam masa pemulihan, dan memiliki komplikasi gagal ginjal. Selain itu juga peserta yang sedang mengkonsumsi obat penurun berat badan serta steroid.

\subsection{Teknik pengambilan sampel}

Metode pengambilan sampel yang dilakukan adalah non probability sampling dengan teknik convenience sampling. Perekrutan sampel awal didapatkan sebanyak 43 orang, namun yang bersedia mengikuti penelitian sebanyak 28 orang, dimana dari 28 orang tersebut terdapat 1 orang yang sulit ditemui hingga penelitian berakhir, sehingga sampel penelitian ini berjumlah 27 orang.

\subsection{Pengumpulan data}

Pengukuran parameter klinis seperti berat badan (timbangan berat badan), tinggi badan (meteran tinggi badan), lingkar perut (meteran), tekanan darah (tensimeter digital) dan gula darah puasa (glucometer/alat pengukur gula darah), dilakukan sebelum dan setelah pemberian intervensi (edukasi). Setelah dilakukan pengukuran parameter klinis pertama, peserta penelitian diberikan intervensi edukasi perubahan gaya hidup dengan bantuan perangkat piring sehat dan buku 
catatan harian makan serta materi edukasi pola makan sehat.

Materi edukasi dilakukan secara personal education diantaranya tentang pentingnya merubah gaya hidup, manfaatnya pada penderita diabetes, komposisi makan sehat (terkait dengan piring sehat), sumber makanan sehat, jenis buah-buahan yang boleh dikonsumsi bagi penderita diabetes melitus, serta batasan konsumsi harian gula, garam dan lemak serta air putih. Intervensi penelitian dilakukan selama 4 minggu dan pengambilan data parameter klinis dilakukan lagi setelah 4 minggu tersebut.

\subsection{Analisis data}

Analisis data yang digunakan adalah statistika deskriptif dan uji beda. Data karakteristik umum subjek penelitian diolah dan dianalisis dengan menggunakan analisis deksriptif. Sebelum melakukan uji beda, dilakukan pengujian distribusi normalitas data dengan menggunakan uji Shapiro-Wilk. Uji beda parameter klinis sebelum dan sesudah diberikan intervensi menggunakan Wilcoxon Signed-rank untuk data yang tidak terdistribusi normal dan paired $t$-test untuk data yang terdistribusi normal. Analisis statistika dilakukan dengan menggunakan bantuan SPSS versi 20 .

\subsection{Pertimbangan etis}

Penelitian ini telah dinyatakan memenuhi kelaikan etik oleh Komisi Etik Universitas Surabaya (sertifikat lulus uji etik No.073/KE/V/2019).

\section{Hasil penelitian}

Karakteristik umum subyek penelitian terangkum dalam Tabel 1. Karakteristik subjek penelitian dikategorikan berdasarkan usia, jenis kelamin, tingkat pendidikan, merokok, mengkonsumsi alkohol, riwayat penyakit keluarga, serta obat yang dikonsumsi. Hasil analisis statistika data parameter klinis pretest dan post test dapat dilihat pada Tabel 2. Hasil analisis deskriptif dari parameter klinis terdapat penurunan hasil rata-rata dari seluruh parameter klinis yang diuji. Hasil uji normalitas data menggunakan Shapiro-Wilk didapatkan tekanan darah diastolik terdistribusi normal dan dilanjutkan analisis uji beda menggunakan paired t-test, sedangkan indeks massa tubuh, lingkar perut, tekanan darah sistolik, dan gula darah puasa terdistribusi tidak normal maka dilanjutkan analisis uji beda menggunakan Wilcoxon Signed-rank. Nilai p-value merupakan hasil dari analisis uji beda yang dilakukan, yaitu hampir seluruh parameter klinis berbeda signifikan antara pretest dan post test-nya, kecuali tekanan darah diastolik $(\mathrm{p}=0,247)$.

\section{Pembahasan}

Penelitian edukasi perubahan gaya hidup telah dilakukan terhadap 27 subjek penelitian, data yang diperoleh kemudian dianalisis dan dikategorikan ke dalam beberapa kategori untuk dibahas.

\subsection{Usia}

Hasil penelitian didapatkan rentang usia terbanyak adalah antara 50-59 tahun sebanyak 8 orang $(29,6 \%)$. Hasil ini sejalan dengan penelitian yang dilakukan oleh Imelda (2019), yang menunjukkan bahwa penderita DM terbanyak berada dalam rentang usia 50-59 tahun $(59,4 \%)$ [14]. Berdasarkan IDF penderita diabetes kebanyakan merupakan orang pada usia produktif (working age) yaitu dalam rentang usia 20-64 tahun sebanyak 72,0\% (352 juta jiwa) dari total populasi dunia jika dibanding dengan orang lanjut usia (older people, > 65 tahun) yaitu sebanyak 27,8\% (111 juta jiwa) dari total populasi dunia [1].

Salah satu faktor risiko diabetes yang tidak dapat dimodifikasi adalah usia. Semakin bertambahnya usia, akan semakin meningkatkan risiko morbiditas dan mortalitas (komplikasi dan kematian) pada penderita diabetes melitus. Menurut Aquarista (2016) bahwa usia $\geq 50$ tahun me- 
Tabel 1. Karakteristik umum subyek penelitian

\begin{tabular}{lll}
\hline Karakteristik & & Total (\%) \\
\hline Jenis kelamin & Perempuan & 51,9 \\
Usia (tahun) & Laki-laki & 48,1 \\
& $30-39$ & 3,7 \\
& $40-49$ & 14,8 \\
& $50-59$ & 44,4 \\
Tingkat pendidikan & $60-69$ & 29,6 \\
& $70-79$ & 7,4 \\
\hline Merokok & Tidak tamat SD & 14,8 \\
& SMP & 14,8 \\
Mengkonsumsi alkohol & SMA & 14,8 \\
& Diploma & 3,7 \\
Riwayat penyakit keluarga & Sarjana & 51,9 \\
& Ya & 14,8 \\
& Tidak & 85,2 \\
\hline & Ya & - \\
& Tidak & 100 \\
\hline & Hipertensi & 7,4 \\
& Diabetes & 88,9 \\
& Dislipidemia & 3,7 \\
& Jantung & 7,4 \\
\hline
\end{tabular}

Tabel 2. Hasil uji normalitas dan analisis data parameter klinis

\begin{tabular}{llllll}
\hline Variabel & \multicolumn{2}{l}{ Nilai parameter klinis } & Shapiro-Wilk & p-value \\
\cline { 2 - 5 } & Pre test & Post test & Pre test & Post test & \\
\hline IMT $(\mathrm{kg} / \mathrm{m} 2)$ & $26,20 \pm 4,88$ & $25,74 \pm 4,96$ & 0,001 & 0,003 & 0,005 \\
LP (m) & $93,74 \pm 11,23$ & $92,06 \pm 10,69$ & 0,025 & 0,106 & 0,005 \\
TDS (mmHg) & $132,37 \pm 16,59$ & $126,41 \pm 11,91$ & 0,231 & 0,008 & 0,013 \\
TDD (mmHg) & $82,70 \pm 9,14$ & $80,44 \pm 6,75$ & 0,856 & 0,182 & 0,247 \\
GDP (mg/dL) & $181,41 \pm 63,72$ & $145,67 \pm 47,46$ & 0,007 & 0,024 & $<0,001$ \\
\hline
\end{tabular}

miliki risiko terjadinya PJK pada penderita DM 3 kali lebih besar dan untuk $\geq 60$ tahun memiliki risiko terjadinya PJK pada penderita DM 4,7 kali lebih besar [15]. Menurut IDF sebanyak 4,2 juta jiwa orang dewasa dengan rentang usia 20-79 tahun meninggal karena diabetes dan komplikasinya pada tahun 2019, dimana hampir setengahnya $(46,2 \%)$ berasal dari orang yang berusia di bawah 60 tahun [1].

Menurut Jelantik dan Haryati (2014) proses menua berlangsung setelah usia 30 tahun dan mengakibatkan perubahan anatomis, fisiologis, dan biokimia. Peningkatan risiko diabetes seiring dengan umur, khususnya pada usia lebih dari 4564 tahun, disebabkan karena pada usia tersebut mulai terjadi peningkatan intoleransi glukosa [16]. Pada usia tua, fungsi tubuh secara fisiologis menurun termasuk sel beta pankreas. Fungsi sel beta pankreas akan mengalami penurunan tergantung dari beban kerja sel (yang dipengaruhi oleh tingkat resistensi insulin serta durasi terjadinya resistensi insulin), karena terjadinya 
penurunan sekresi atau resistensi insulin sehingga kemampuan fungsi tubuh terhadap pengendalian glukosa darah yang tinggi kurang optimal, dan jika disertai dengan berat badan berlebih di usia $>45$ tahun, akan semakin membuat tubuh tidak peka terhadap insulin [16].

Pertambahan usia juga akan meningkatkan risiko terjadinya hipertensi. Terjadinya perubahan struktur (semakin menyempit dan menjadi lebih kaku) pada pembuluh darah besar (aorta) akan menyebabkan terjadinya peningkatan tekanan darah sistolik [17]. Pertambahan usia juga menyebabkan perubahan hormonal, dan jika hal ini diiringi dengan gaya hidup sedentari (kurang gerak) akan mengakibatkan penumpukan lemak tubuh dan otot tubuh akan mulai berkurang. Pertambahan usia juga menyebabkan penurunan jaringan otot yang diikuti penurunan laju metabolisme, sehingga lebih berisiko tinggi menjadi obesitas [18].

\subsection{Jenis kelamin}

Hasil penelitian didapatkan sebanyak 51,9\% subjek berjenis kelamin pria dan sebanyak 48,1\% berjenis kelamin wanita. Distribusi penderita diabetes melitus sangat bervariasi jika dilihat berdasarkan jenis kelamin. Hasil penelitian Yang (2010) di beberapa provinsi dan kotamadya di negara Cina pada periode Juni 2007-Mei 2008 juga menyatakan hal serupa bahwa angka kejadian diabetes melitus tipe 2 pada pria lebih banyak dibandingkan dengan wanita [19]. Namun, berbeda dengan IDF Diabetes Atlas edisi 9 tahun 2019 yang menyatakan bahwa prevalensi diabetes pada wanita dalam rentang usia 20-79 tahun lebih tinggi 17,2 juta jiwa dibandingkan dengan pria [1]. Berdasarkan Riskesda tahun 2018 juga menyatakan bahwa penderita diabetes melitus di Indonesia lebih banyak berjenis kelamin wanita $(1,8 \%)$ dibandingkan dengan pria $(1,2 \%)$ [20]. Perbedaan ini dapat disebabkan karena adanya perbedaan jumlah ataupun kondisi responden pada masing-masing penelitian tersebut.

\subsection{Tingkat pendidikan}

Tingkat pendidikan subjek penelitian terbanyak adalah pendidikan sarjana (51,9\%). Hal ini sejalan dengan hasil Riskesda tahun 2018 yang menyatakan bahwa penderita diabetes melitus tertinggi merupakan tamatan pendidikan setingkat D1/D2/D3/PT yang merupakan kategori jenjang tertinggi pada hasil Riskesda 2018 [20]. Penderita diabetes melitus agar dapat lebih memahami serta mengatur dirinya sendiri maka diperlukan pendidikan [21]. Tingkat pendidikan yang baik akan sangat memudahkan seseorang menerima pengaruh dari luar, sehingga lebih terbuka pada bermacam-macam informasi, terutama yang terkait dengan kesehatan [22]. Pendidikan juga berpengaruh dalam pengambilan keputusan untuk memilih jenis makanan apa yang akan dikonsumsinya dan berakibat pada peningkatan kualitas hidupnya [23].

Namun pada penelitian ini subjek penelitian kebanyakan memiliki tingkat pendidikan tinggi, hal tersebut kemungkinan dapat dipengaruhi dari faktor lain seperti jenis pekerjaan dan aktifitas fisik dari subjek penelitian, dimana seseorang yang memiliki pendidikan rendah cenderung akan mengandalkan tenaga untuk menghidupi hidupnya, sehingga akan lebih banyak memiliki aktifitas fisik. Hal ini berbanding terbalik dengan seseorang yang memiliki pendidikan tinggi yang bekerja kantoran yang memiliki aktifitas fisik lebih rendah dan cenderung mengarah pada gaya hidup sedentari [24].

\subsection{Riwayat penyakit keluarga}

Dari total subyek penelitian, hampir seluruh subyek $(88,9 \%)$ memiliki riwayat keluarga diabetes. Hasil ini sesuai dengan penelitian Afriwandi (2012) dimana sebanyak 52,6\% dari total subjek penelitian memiliki faktor riwayat diabetes melitus dalam keluarganya [25]. Risiko diabetes erat berkaitan dengan riwayat penyakit keluarga terutama yang memiliki hubungan darah (ayah, ibu, saudara, dan anak). Selain itu, keluarga juga pas- 
tinya memiliki kebiasaan yang sama seperti pola makan dan pola hidup. Jika salah satu orang tua menderita diabetes melitus maka risiko anaknya akan menderita diabetes adalah sebesar 15\% dan akan meningkat jika kedua orang tuanya menderita diabetes melitus menjadi 75\% [26]. Berdasarkan Isnaini dan Ratna sari (2018), seseorang yang memiliki riwayat keluarga diabetes melitus akan berpeluang 10,938 kali lebih besar menderita diabetes melitus dari pada seseorang yang tidak memiliki riwayat keluarga diabetes melitus[27].

\subsection{Merokok}

Berdasarkan hasil penelitian, sebanyak 14,8\% subjek penelitian merokok, yang semuanya adalah pria. Menurut penelitian Akter, Goto dan Mizoue (2017) menyebutkan bahwa risiko kejadian diabetes melitus tipe 2 meningkat 16\% jika seseorang merokok 10 batang per hari, jika dibandingkan dengan seseorang yang tidak pernah merokok selama 10 tahun [28]. Hubungan merokok dengan diabetes melitus tipe 2 masuk akal, karena merokok dapat menyebabkan resistensi insulin atau tidak memadainya kompensasi sekresi insulin dikarenakan berbagai efek yang mendasarinya, termasuk stress oksidatif, peradangan, dan disfungsi endotel. Nikotin pada rokok juga dapat memberikan efek toksik langsung pada fungsi sel beta [28].

Selain itu, kebiasaan merokok berkontribusi tinggi terhadap kejadian penyakit jantung koroner pada penderita diabetes melitus. Berdasarkan penelitian yang dilakukan oleh Arifin (2010), menyebutkan bahwa faktor risiko merokok berkontribusi tinggi untuk kejadian penyakit jantung koroner. Hasil dari sebuah meta analisis menyatakan bahwa kebiasaan merokok memiliki korelasi positif secara signifikan terhadap kematian pada penderita diabetes melitus tipe 2 (RR1,53, 95\% CI: 1,44-1,63), serta secara signifikan berpengaruh terhadap risiko kejadian kardiovaskular pada penderita diabetes (jika dibandingkan dengan seseorang yang tidak pernah merokok), yaitu Cardiovascular Disease/CVD (RR 1,09, 95\% CI: 1,05-1,13) dan Coronary Heart Disease/CHD (RR 1,14, 95\% CI: 1,00-1,30) [29].

Nikotin yang ada di dalam rokok akan merangsang sistem saraf otonom untuk melepaskan katekolamin sehingga dapat menyebabkan penggumpalan darah dan membuat tekanan darah meningkat serta denyut jantung juga meningkat. Selain itu karbon monoksida yang terdapat di dalam rokok juga menyebabkan penurunan persediaan oksigen untuk jaringan miokardial akibat dari desaturase hemoglobin, sehingga aterosklerosis lebih cepat terjadi [30].

\subsection{Obat yang digunakan}

Salah satu pengendalian penderita diabetes melitus adalah melakukan pemantauan terhadap kadar glukosa darah agar sebisa mungkin terkendali. Kadar glukosa darah puasa digunakan sebagai indikator pengendalian dikarenakan lebih murah dan mudah serta cepat (langsung bisa terpantau), selain itu kadar glukosa darah juga berkorelasi dengan kadar HbA1C. Menurut PERKENI tahun 2015 diabetes melitus terkendali dengan baik jika kadar gula darah, kadar lipid, dan HbA1C mencapai kadar yang diharapkan, serta status gizi maupun tekanan darah sesuai dengan target yang ditentukan [11].

Pada penelitian ini sebanyak $29,6 \%$ pengguna insulin, 40,7\% pengguna oral anti diabetes (OAD), dan 29,6\% kombinasi insulin dan OAD. Jika dijabarkan lebih rinci lagi, sebanyak 22,2\% menggunakan anti diabetes tunggal, 51,9\% menggunakan dua kombinasi, 14,8\% menggunakan 3 kombinasi, dan sebanyak 11,1\% menggunakan 4 kombinasi obat anti diabetes. Menurut PERKENI tahun 2015 terapi diabetes sangat tergantung dari masing-masing individu, serta respon individu tersebut terhadap pengendalian kadar glukosa darahnya. Jika dengan obat anti diabetes tunggal kadar glukosa darahnya sudah bisa terkontrol, maka cukup dengan satu macam 
obat saja. Sebaliknya, jika dengan satu macam obat, kadar glukosa darah tidak dapat terkontrol, maka selain perlu meningkatkan dosis bisa juga dengan menambahkan satu macam jenis obat yang berbeda golongan untuk mencapai target kadar glukosa darah [11].

\subsection{Parameter klinis}

Analisis deskriptif dari parameter klinis pre test dari indeks massa tubuh $(26,20 \pm 4,88)$, lingkar perut $(93,74 \pm 11,23)$, tekanan darah (TDS=132,37 $\pm 16,59 ; \quad$ TDD $=82,70 \pm 9,14$ ) serta gula darah puasa $(181,41 \pm 63,72)$ rata-rata mengalami penurunan pada saat pengukuran post test terhadap indeks massa tubuh $(25,74 \pm 4,96)$, lingkar pinggang $(92,06 \pm 10,69)$, tekanan darah (TDS=126,41 $\pm 11,91 ; \quad T D D=80,44 \pm 6,75$ ), dan gula darah puasa $(145,67 \pm 47,46)$. Selain analisis deskriptif, dilakukan pula uji beda dengan menggunakan Wilcoxon Signed Rank dan terdapat perbedaan signifikan pada indeks massa tubuh $(\mathrm{p}=0,005)$, lingkar pinggang $(\mathrm{p}=0,005)$, tekanan darah sistolik $(p=0,013)$ dan gula darah puasa $(\mathrm{p}=0,000)$.

Penerapan pola diet pada penelitian ini mirip dengan pola diet DASH (Dietary Approach to Stop Hypertension) dikarenakan untuk penderita diabetes dapat melakukan pengaturan pola makan seperti orang pada umumnya, hanya saja ada hal yang perlu dipertimbangkan pada pola makan penderita diabetes dalam makanannya yang dikenal dengan 3J, yaitu Jenis, Jumlah, dan Jadwal. Berdasarkan penelitian Foster et al. (2011) yang melakukan penelitian intervensi gaya hidup terhadap penurunan berat badan, dimana penurunan berat badan tanpa diet sebagai kontrol dibandingkan dengan penurunan berat badan dengan melakukan diet saja, olahraga saja serta kombinasi diet dan olahraga menyatakan bahwa kelompok yang melakukan diet saja mengalami penurunan berat badan sebanyak 8,5\% $(\mathrm{p}<0,0001)$, kelompok yang melakukan olahraga saja mengalami penurunan sebanyak $2,4 \%$ $(p=0,034)$ dan kelompok yang melakukan diet dan aktifitas fisik mengalami penurunan berat badan 10,8\% $(\mathrm{p}<0,0001)$ dibandingkan dengan kelompok kontrol [31].

Berdasarkan penelitian yang dilakukan oleh Pustika (2011) yang melakukan konseling gizi dan gaya hidup selama 8 minggu pada penderita diabetes melitus, didapatkan perubahan yang signifikan pada kelompok yang diberikan edukasi terhadap indeks massa tubuh $(\mathrm{p}=0,009)$, lingkar pinggang $(\mathrm{p}=0,05)$, tekanan darah sistolik ( $p=0,031)$, tekanan darah diastolik $(p=0,014)$, serta gula darah puasa $(p=0,001)$ dimana dijelaskan bahwa penurunan ini dikarenakan adanya kesadaran untuk merubah pola dalam memilih makanan dan minuman yang dikonsumsi [32].

Keterbatasan dalam penelitian ini adalah keikutsertaan penderita diabetes melitus yang memenuhi persyaratan sangat kecil dari total subjek, serta tidak adanya kontrol dalam penelitian ini yang digunakan sebagai pembanding.

\section{Kesimpulan}

Kesimpulan dari hasil penelitian ini menyatakan bahwa edukasi perubahan gaya hidup berpengaruh signifikan terhadap gula darah puasa, indeks massa tubuh, lingkar perut, dan tekanan darah sistolik namun tidak berpengaruh signifikan terhadap tekanan darah diastolik.

\section{Daftar Pustaka}

1. International Diabetes Federation. The IDF Diabetes Atlas 9th edition. Brussel Belgium: International Diabetes Federation; 2019.

2. American Diabetes Association. Standards of Medical Care in Diabetes 2020. USA: American Diabetes Association; 2012.

3. World Health Organization. Double Burden of Disease and WHO NCD Country Profile 2014. Switzerland: World Health Organization; 2010. 
4. Robinson E, Jones A, Whitelock V, Mead BR, Haynes A. (Over)eating out at major UK restaurant chains: observational study of Energy content of main meals. British Medical Journal. 2018;363:k4982.

5. Nilsen AC. Majalah Appetite Journey. 2008; 5(1):22.

6. Wiwied DL. Hubungan Kebiasaan Konsumsi Fast Food, Aktifitas Fisik, Pola Konsumsi, Karakteristik remaja dan Orang Tua dengan Indeks Massa Tubuh. J Kesehatan Masy. 2012;(1):542-53.

7. Chan TF, Lin WT, Huang HL, Lee CY, Wu PW, Chiu YW, et al. Consumption of Sugar-sweetened beverages is associated with components of the metabolic syndrome in adolescents. Nutrients. 2014;6(5):2088-103.

8. Malik VS, Popkin BM, Bray GA, Després JP, Willett WC, Hu FB.'Sugar-sweetened beverages and risk of metabolic syndrome and type 2 diabetes: a meta-analysis'. Diabetes Care. 2010; 33(11):247783.

9. Kemenkes RI. Studi Diet Total: Potret Pola MakanPenduduk Indonesia SaatIni [Diakses pada 20 September 2019]. Tersedia di: https://www. kemkes.go.id/article/view/15041400003/ studi-diet-total-potret-pola-makan-pendudukindonesia-saat-ini.html.

10. Siswanto. Survey of individual food consumption Indonesia 2014. Ministry of Health Republic of Indonesia; 2014.

11. PERKENI. Konsensus Pengendalian dan Pencegahan Diabetes Melitus Tipe 2 di Indonesia; 2015.

12. Kemenkes RI. (2018). Isi Piringku Sekali Makan [Online]. Tersedia di: http://www.p2ptm. kemkes.go.id/infographic-p2ptm/obesitas/ page/14/isi-piringku-sekali-makan.

13. American Diabetes Association. Standards of Medical Care in Diabetes 2018. USA: American Diabetes Association; 2018.

14. Imeda SI. Faktor-faktor yang mempengaruhi terjadinya diabetes melitus di Puskesmas Harapan Raya tahun 2018. Scientia Journal. 2019; 8(1): 28-39.

15. Aquarista NC. Perbedaan Karakteristik Penderita
Diabetes Melitus Tipe 2 dengan dan Tanpa Penyakit Jantung Koroner. Jurnal Berkala Epidemiologi. 2016;5(1):37-47.

16. Jelantik I, Haryati E. Hubungan Faktor Risiko Umur, Jenis Kelamin, Kegemukan dan Hipertensi dengan Kejadian Diabetes Melitustipe II di Wilayah Kerja Puskesmas Mataram. Media Bina Ilmiah. 2014; 8(1):39-44.

17. Novitaningtyas T. Hubungan Karakteristik (Umur, Jenis Kelamin, Tingkat Pendidikan dan Aktivitas Fisik) dengan Tekanan Darah pada Lansia di Kelurahan Makam Haji Kecamatan Kartasura Kabupaten Sukoharjo. Master's thesis. Surakarta: Universitas Muhammadiyah Surakarta; 2014.

18. Garko MG. Overweight and Obesity Epidemic In America - Part V: Non Modifiable Risk Factors. Let's Talk Nutrition; 2010.

19. Yang W, Lu J, Weng J, Jia W, Ji L, Xiao J, Shan Z, Liu J, Tian H, Ji Q Zhu D, Ge J, Lin L, Chen L, Gou X, Zhao Z, Li Q Zhou Z, Shan G, He J; Prevalence of Diabetes among Men and Women in China. New England Journal of Medicine. 2010;362 (12):1090-101.

20. Balitbang Kemenkes RI. Riset kesehatan dasar: Riskesdas. Jakarta; 2018.

21. Stipanovic AR. The Effect of Diabetes Education on Self Efficacy and Self Care; 2002.

22. Tamara E, Bayhakki, and Nauli A. Hubungan Antara Dukungan Keluarga dan Kualitas Hidup Pasien Diabetes Melitus Tipe II di RSUD Arifin Achmad Provinsi Riau. Jurnal Online Mahasiswa Program Studi Ilmu Keperawatan. 2012;1(2).

23. Magdalena, Mahpolah, YusufA. Faktor-faktor yang berhubungan dengan sindrom metabolik pada penderita rawat jalan di RSUD Ulin Banjarmasin. Jurnal Skala Kesehatan. 2014;5(2):1-6.

24. Fitriyani. Faktor Risiko Diabetes Melitus Tipe 2 di Puskesmas Kecamatan Citangkil dan Puskesmas Kecamatan Pulo Merak Kota Cilegon. Skripsi. Fakultas Kesehatan Masyarakat, Depok: Universitas Indonesia; 2012.

25. Afriwandi. Faktor-Faktor Penyebab Terjadinya Diabetes Melitus di Ruangan Murai RSUD Arifin Ahmad Pekanbaru; 2012.

26. Diabetes UK, (2019) Diabetes and Genetics 
[Online], Tersedia di https://www.diabetes. co.uk/diabetes-and-genetics.html.

27. Isnaini N, Ratnasari. Faktor Risiko Mempengaruhi Kejadian Diabetes Melitus Tipe Dua. Jurnal Keperawatan dan Kebidanan Aisyiyah. 2018;14(1):59-68.

28. Akter S, Goto A, and Mizoue T. Smoking and the risk of type 2 diabetes in Japan: A systematic review and meta-analysis. Journal of Epidemiology. 2017;27(12);553-61.

29. Arifin A. Overview and Phatophysiology of Hypertension, dalam One Day Symposium Update Management Of Hypertension and Its Complication. Skripsi. Fakultas Kedokteran
Universitas Negeri Surakarta; 2010:9-12.

30. Price S. Buku Patofisiologi: Konsep Klinis Proses Penyakit (6th ed.). Jakarta: EGC; 2002.

31. Foster-Schubert KE, Alfano CM, Duggan CR, Xiao L, Campbell KL, KongA, Bain CE, Wang CY, Blackburn GL, McTiernan A. Effect of Diet and Exercise, Alone or Combined, on Weight and Body Composition in Overweight-to-Obese Postmenopausal Women. Obesity. 2011;20(8):1628-38.

32. Pusthika IO. Pengaruh Frekuensi Konseling Gizi dan Gaya Hidupter hadap Indeks Massa Tubuh, Lingkar Pinggang, Tekanan Darah, dan Glukosa Darah pada Penderita Diabetes Melitus. Skripsi. Semarang: Universitas Diponegoro; 2011. 